\title{
THE EFFECT OF SAUCE OF L. LEUCOCEPHALA SEEDS (LEUCAENA LEUCOCEPHALA [LAM.] DE WIT) ON LOWERING BLOOD GLUCOSE IN HYPERGLYCEMIC MICE
}

\author{
SARAH ZAIDAN, RIA DEBBY BP, SYAMSUDIN ABDILLAH* \\ Department of Pharmacology, Faculty of Pharmacy, University of Pancasila, South Jakarta, Indonesia. \\ Email: syamsudinabdillah@gmail.com
}

Received: 07 March 2018, Revised and Accepted:25 March 2018

\section{ABSTRACT}

Objective: The research to investigate that the source of Leucaena leucocephala can lower blood glucose levels in hyperglycemic mice.

Methods: In this study, 42 mice were divided into 7 groups each consisted of 6 mice: Normal Group I, Group II (metformin positive control), Group III (negative control), Group IV (sauce of L. leucocephala at a dose of $0.1 \mathrm{ml}$ ), Group V (sauce of L. leucocephala at a dose of $0.2 \mathrm{ml}$ ), Group VI (sauce of L. leucocephala with doses of $0.4 \mathrm{ml}$ ), and Group VII (sauce of L. leucocephala at a dose of $0.8 \mathrm{ml}$ ). The dosage of Group II, IV, V, VI, and VII was orally administered. Blood glucose levels in mice were observed during normal conditions and after administration of 200 mg/kg bw alloxan intraperitoneally (alloxan-induced mice). On day $0,3,7$, and 14, blood was taken from the tail and glucose levels were measured with a glucometer.

Results: Data were analyzed by one-way analysis of variance followed by LSD test. Based on the results, the sauce at a dose of 0.8 ml was able to lower the blood glucose levels up to normal blood glucose levels.

Conclusion: There was not significantly different between the groups given sauce of L. leucocephala at a dose of $0.8 \mathrm{ml}$ with the group given metformin (positive control).

Keywords: Hyperglycemic, Leucaena leucocephala (Lam.) de Wit, Alloxan, Sauce.

(C) 2018 The Authors. Published by Innovare Academic Sciences Pvt Ltd. This is an open access article under the CC BY license (http://creativecommons. org/licenses/by/4. 0/) DOI: http://dx.doi.org/10.22159/ajpcr.2018.v11s1.26570

\section{INTRODUCTION}

Most Indonesian people's dietary habit does not pay attention to the nutrition balance which could bring negative consequences such as the rise of degenerative diseases, including diabetes mellitus; this disease is a disorder of carbohydrate metabolism which is characterized by high blood glucose levels. One of the characteristics of early disease is quickly feeling hungry then made them eat a lot [1]. Diabetes mellitus disease usually lasts for a lifetime. A recent study from the International Diabetes Federation in 2012 revealed that people with diabetes mellitus worldwide reached 371 million people. Whereas, Indonesia entered the order of seven countries with most diabetics. The first rank is China with 92.3 million people, India 63 million, 24.1 million, Brazil 13.4 million, Russia 12.7 million, Mexico 10.6 million, and Indonesia with 7.6 million people diabetic patients [2].

During this treatment, diabetes mellitus is usually performed by given an oral antidiabetes or with insulin injection. However, both treatments are less accessible to Indonesians as well as because of the economic factors are also due to the adverse side effects of treatment with insulin or orally, then many medicinal plants are developed to treat this disease as a cheaper alternatives for alternative healing [3]. Medicinal plants that have potential to be developed are associated with a decreasing blood's glucose level that is Leucaena leucocephala. Part of this plant that serves to lowering blood's glucose levels are the seeds $[4,5]$.

Research on the effect of antidiabetic L. leucocephala has been carried out previously, in which extracts from L. leucocephala has active compounds such as flavonoids that can lower blood glucose [6]. Based on previous studies, methanol extract from L. leucocephala with doses of $0.25 \mathrm{~g} / \mathrm{kgBB}$ given in oral mice, which were propagated with allot potential in lowering blood glucose levels [7]. In the study conducted by Tri Bowo, it was found that the fraction of ethyl acetate extract had a decrease in the blood glucose caused by alloxan in the dose of $100 \mathrm{mg} / \mathrm{kg}$ BW and $500 \mathrm{mg} / \mathrm{kg}$ BW [8].
In addition to having many benefits, $L$. leucocephala have also been known to have toxin mimosine compounds [9]. Mimosine can cause growth slowdown, hair loss, swollen thyroid gland, and reduce fertility [10]. However, based on the study conducted by Dita, mimosine levels can be minimized optimally through the fermentation process [11]. Sauce is one of the forms of preparation made through the fermentation process. Based on this description, in this study, a hypoglycemic impression test of sauce of $L$. leucocephala in mice that was first encouraged by alloxan where alloxan was a diabetogenic agent with a cheaper price compared with streptozotocin. The results of this study are expected to be used as information by the public about the effect of antidiabetic sauce of L. leucocephala

\section{MATERIALS AND METHODS}

Materials

The material used in this research is sauce made from Leucaena leucocephala obtained from previous research [12]. The sauce composition can be seen in Table 1. The experimental animals used were male mice (Mus musculus) DDY strain 2-3 months old with average weight of 20-30 g of 42 heads. While the ingredients for hypoglycemic activity test are water, alloxan tetrahydrate, and metformin.

Tool

The tools used in the study were a syringe, oral sonde, cage of mice as well as food and beverage outlets, an analytical balance, pipette, cotton, scissors, glucometers and test strips glucose, flask, and glassware.

\section{Methods}

Hypoglycemic activity test

a. All mice maintained for 1 week ( 7 days), given the same food and drinks.

b. On the $7^{\text {th }}$ day, each mouse that will be used for research is fasted for $\pm 16 \mathrm{~h}$, then taken early blood samples by cutting the tail of the mouse. Levels obtained are normal blood glucose levels. 
Table 1: Composition of sauce L. leucocephala

\begin{tabular}{ll}
\hline Material & Formula (g) \\
\hline L. leucocephala & 750 \\
Inokulum A. oryzae (\%) & 5 \\
Salam leaf & 0.3 \\
Lime leaves & 0.3 \\
Galangal & 1.4 \\
Fennel & 1 \\
Palm sugar & 300 \\
Water (liter) & 2 \\
Salt & 500 \\
\hline L. leucocephala: Leucaena leucocephala, A. oryzae: Aspergillus oryzae
\end{tabular}

L. leucocephala: Leucaena leucocephala, A. oryzae: Aspergillus oryzae

c. All mice were divided into seven groups, each group (consisting of six mice) was treated as follows:

1. Group I normal control (not injected alloxan).

2. Group II positive controls were given metformin.

3. Group III negative control.

4. Group IV was given sauce of L. leucocephala with dose $0.1 \mathrm{ml}$.

5. Group V was sauce of L. leucocephala at a dose of $0.2 \mathrm{ml}$.

6. Group VI was given sauce of $L$. leucocephala at a dose of $0.4 \mathrm{ml}$.

7. Group VII was given a sauce of $L$. leucocephala at a dose of $0.8 \mathrm{ml}$.

d. Mice made diabetes by injection of alloxan tetrahydrate (dose $200 \mathrm{mg} / \mathrm{kg} \mathrm{bw}$ ) intraperitoneally, except Group I (normal group), then maintained for 3 days for hyperglycemia.

e. On the $3^{\text {rd }}$ day, blood sampling is taken from the tail of each mouse before it is given test preparation and measuring the blood glucose level of each mouse. After the measurement of blood glucose levels, each of the mice received one kind of dose with the appropriate dosage administered orally. All are given daily for 14 days.

f. Blood samples of mice from each group were taken and measured blood glucose levels with glucometer. Measurements were performed on days $0,3,7$, and 14 .

g. Every time blood sampling of mice, before the mice should be fasted for approximately $16 \mathrm{~h}$.

\section{Data analysis}

Data were analyzed by normality test and homogeneity test. Data were analyzed by one-way analysis of variance (ANOVA) test if the data were normal and homogeneous. If the data are not normal and homogeneous, then the data are analyzed by Kruskal-Wallis test. If there is a significant difference in the one-way ANOVA test, then it is continued with the smallest significant differential (BNT) test. Moreover, if there is significant difference in Kruskal-Wallis test, then it is continued with Mann-Whitney test.

\section{RESULTS}

Before use in the experiment, all mice from each group were weighed, then maintained for 1 week. Then, all the mice were given treatment according to the division of the group for 14 days. On day 0 (hyperglycemia), 3,7 , and 14, weigh the mice to obtain data of weight.

\section{DISCUSSION}

From Tables 2 and 3, it can be seen that before treatment hyperglycemic mice of Group II, IV, V, VI, and VII decreased body weight on day 0 and after treatment Group III hyperglycemic mice lost weight on day 7. This is due to the depletion of fat cells and proteins to meet energy needs because they cannot be met from glucose metabolism. In Groups II, III, and IV increased weight until day 14 after treatment.

In the initial condition of the experiment, intraperitoneal alloxan induction was performed for the whole group at a dose of $200 \mathrm{mg} / \mathrm{kg} \mathrm{bw}$, but Group I (normal) was not induced with alloxan because it was used as a comparison. After 3 days from the time of alloxan administration in Groups II, III, IV, V, VI, and VII, there was an increase in blood glucose levels, which averaged $130-158 \mathrm{mg} / \mathrm{dL}$. This shows that alloxan can show hyperglycemic effect on day 3. After 3 days of alloxan administration, treatment began to be given to Group II, IV, V, VI, and VII.

On the $3^{\text {rd }}$ day, blood glucose levels of the mice given sauce of L. leucocephala with a dose of $0.1 \mathrm{ml}$ did not decrease blood glucose levels. After the administration sauce of L. leucocephala with doses of $0.2 \mathrm{~mL}, 0.4 \mathrm{~mL}$, and $0.8 \mathrm{~mL}$, the average blood glucose level decreased by $133.8-137.2 \mathrm{mg} / \mathrm{dL}$, but the blood sugar level still categorized as hyperglycemic.

On the $7^{\text {th }}$ day after treatment, blood glucose levels in mice Group V, VI, and VII and metformin group decreased. On the $7^{\text {th }}$ day after treatment, Group mice II, IV, V, and VI still had hyperglycemia. The group of mice who had decreased blood glucose level until they reached normal blood glucose level only Group VII, where the average blood glucose level on the $7^{\text {th }}$ day was $99.8 \mathrm{mg} / \mathrm{dL}$. However, for Group IV, mice given sauce of $0.1 \mathrm{ml}$ until day 7 continued to increase blood glucose levels. Increased blood glucose levels were also experienced by Group III (negative control), in which the group was not treated.

On day 14 after treatment, blood glucose levels in Groups II, V, VI, and VII decreased. In the positive group of mice given metformin decreased blood glucose levels to reach normal blood glucose levels. Where the mean blood glucose levels of the positive group on day 14 were $102.2 \mathrm{mg} / \mathrm{dL}$. In Group IV, mice given sauce of L. leucocephala with a small dose of $0.1 \mathrm{ml}$, blood glucose levels continued to increase until day 14, where the average blood glucose level from Group IV was $151.7 \mathrm{mg} / \mathrm{dL}$. Meanwhile, Groups V and VI continued to decrease blood glucose levels but were still categorized in hyperglycemic states because the mean blood glucose levels of Groups V and VI were $129.7 \mathrm{mg} / \mathrm{dL}$ and $120.6 \mathrm{mg} / \mathrm{dL}$. For Group III (negative control), blood glucose levels decreased when compared with day 7 , where the average blood glucose level from Group III was $130.7 \mathrm{mg} / \mathrm{dL}$ and still categorized hyperglycemic. In Group VII mice, there was a decrease in glucose levels, where the average blood glucose level was $97.8 \mathrm{mg} / \mathrm{dL}$ and was said to have achieved normal blood glucose levels.

Based on these data, it can be seen that sauce of $L$. leucocephala with a dose of $0.8 \mathrm{ml}$ can lower blood glucose levels of mice to normal. This can be seen from the statistical analysis of the difference of blood glucose level of mice before and after treatment, where blood glucose level from Group VII there is no significant difference with Group II which is a positive control.

On the results of weight measurements from day 0 (after alloxan feeding) until day 3, all groups on average gain weight unless Group III is a negative control. On the $14^{\text {th }}$ day, weight gain was experienced by Groups I, II, IV, and V, but weight gain was not experienced by Groups VI and VII. In the Group VII, initially gained weight from day 0 (hyperglycemic state, after alloxan induction) up to day 7 , but on the $14^{\text {th }}$ day, all mice the group is on average experiencing weight loss. This may be due to the side effects of mimosine that still exist in L. leucocephala, which are used as the base ingredients in sauce, because according to research conducted by Syamsudin et al., the extract of L. leucocephala given to pregnant mice can reduce fetal weight along with increasing dosing [9]. L. leucocephala is also known to cause young cows that eat L. leucocephala in the long term will decrease body weight [10].

In previous studies, it has been proved that L. leucocephala can lower blood glucose levels in hyperglycemic mice [5-8]. L. leucocephala are known to have active compounds that can stimulate insulin secretion in the pancreas, the active compound is flavonoids [6]. Cahyono et al. in his research said that $L$. leucocephala has an active compound that is flavonoids that can lower blood glucose levels. The study also used alloxan as an inducer. Alloxan has a destructive effect on pancreatic $\beta$ cells, in which alloxan is a powerful oxidizer that produces high amounts of free radicals that give rise to oxidative stress. Oxidative stress is a condition where there is an imbalance between free radicals and antioxidants. The situation damages pancreatic $\beta$ cells, 
Table 2: Mean weight data of mice (g)

\begin{tabular}{|c|c|c|c|c|c|c|c|}
\hline Time (day) & Group I & Group II & Group III & Group IV & Group V & Group VI & Group VII \\
\hline Initial & $27.8 \pm 2.2$ & $27.4 \pm 1.6$ & $26.4 \pm 2.1$ & $26.4 \pm 1.7$ & $27.9 \pm 1.9$ & $27.9 \pm 1.3$ & $27.1 \pm 1.9$ \\
\hline 0 & $29.3 \pm 2.6$ & $24.9 \pm 2.1$ & $29.8 \pm 2.1$ & $25.5 \pm 1.4$ & $26.4 \pm 1.9$ & $27.3 \pm 1.2$ & $26.9 \pm 1.5$ \\
\hline 3 & $29.3 \pm 3.0$ & $26.5 \pm 1.6$ & $30.1 \pm 1.3$ & $26.9 \pm 1.9$ & $27.5 \pm 2.8$ & $27.2 \pm 1.7$ & $26.6 \pm 1.4$ \\
\hline 7 & $31.8 \pm 1.4$ & $27.2 \pm 1.2$ & $26.8 \pm 1.5$ & $29.9 \pm 2.7$ & $30.2 \pm 4.1$ & $28.3 \pm 2.8$ & $24.8 \pm 2.4$ \\
\hline 14 & $34.03 \pm 2.2$ & $28.6 \pm 1.3$ & $25.2 \pm 1.4$ & $32 \pm 2.7$ & $32.2 \pm 5.8$ & $27.7 \pm 3.9$ & $23.2 \pm 1.6$ \\
\hline
\end{tabular}

Table 3: Mean data on blood glucose levels of mice (mg/dL)

\begin{tabular}{lllllll}
\hline Time & Group I & Group II & Group III & Group IV & Group V & Group VI \\
\hline Initial & $81.3 \pm 10.2$ & $90.5 \pm 8.7$ & $79 \pm 12.9$ & $80 \pm 12.5$ & $85.2 \pm 15.2$ & $75.8 \pm 10.1$ \\
0 & $91.7 \pm 7.2$ & $158 \pm 23.2$ & $130 \pm 9.1$ & $136.5 \pm 19.1$ & $156.8 \pm 15.3$ \\
3 & $82.7 \pm 10.9$ & $130.5 \pm 17.5$ & $137.5 \pm 10.6$ & $140 \pm 9.7$ & $137.2 \pm 11.9$ \\
7 & $77.2 \pm 5.1$ & $123 \pm 13.3$ & $142.2 \pm 7.7$ & $140 \pm 8.8$ & $134.8 \pm 11.3$ \\
14 & $87.5 \pm 12.7$ & $102.2 \pm 11.9$ & $130.7 \pm 14.8$ & $151.7 \pm 9.3$ & $129.7 \pm 12.9$ \\
\hline
\end{tabular}

causing increased blood glucose levels; whereas, flavonoids found in L. leucocephala have antioxidant activity that can inhibit free radicals so that L. leucocephala has hypoglycemic effect [8].

\section{CONCLUSION}

Sauce of L. leucocephala with dose $0.2 \mathrm{ml}, 0.4 \mathrm{ml}$, and $0.8 \mathrm{ml}$ can decrease blood glucose level of hyperglycemic mice. However, only sauce with a dose of $0.8 \mathrm{ml}$ alone can reduce blood glucose to normal levels.

\section{ACKNOWLEDGMENT}

Thanks for laboratory of lectures Faculty of Pharmacy University of Pancasila.

\section{REFERENCES}

1. Jariyah MP. The Effect of Hypoglycemic Pedada Flour (Sonneratia caseolaris (L.) ENG) in Alloxan-Induced Wistar Rats. Surabaya: National Development University; 2013. p. 4

2. Rosalina. The Threat of Diabetes in Indonesia Increases. Tempo Sep 2013.

3. Widowati L, Dzulkarnaen B. Sa'roni Medicinal Plants for Diabetes Mellitus. Mirror World Medicine. Center for Pharmaceutical Research and Development, Research and Development of Health Department of the Republic of Indonesia; 1997. p. 53-7.

4. Aderibigbe SA, Adetunji OA, Odeniyi MA. Antimicrobial and pharmaceutical properties of the seed oil of Leucaena leucocephala (Lam.) De Wit (Leguminosae). Afr J Biomed Res 2011;14:64.
5. Talubmook C, Buddhakala N. Hypoglycemic and hypolipidemic properties of leaf extracts from Phyllanthus acidus (L.) Skeels., Leucaena leucocephala (Lam.) De wit. and Psidium guajava (L.) in streptozotocin-induced diabetic rats. GTSF Int J Biosci 2013;2:30.

6. Sandra F. Effect of Seed Extract of (Leucaena leucocephala (Lmk) De Wit) on Blood Glucose Level and Histopathology Image of Pancreas $\beta$ Cells of Male White Rat Induced Streptozotosin (Thesis). Jakarta: Pharmacy Faculty of Pancasila University; 2009.

7. Tiara. Influence of Flavonoid Fraction from Extra Methanol Seed (Leucaena leucocephala L.) to Blood Glucose Level of Mice Induced by Alloxan (Thesis). Jakarta: Faculty of Pharmacy Universitas Pancasila; 2004.

8. Chahyono TB, Maulani A, Ridwan M, Syarifah AN. Antidiabetic drug ethyl acetate fraction of Leucaena leucocephala extract in Wistar aloxan induced. International Conference: Research and Application on Traditional Complementary and Alternative Medicine in Health Care (TCAM); 2012.

9. Syamsudin, Rizkiyan Y, Darmono. The teratogenic effect of $L$. leucocephala seed methanol extract (Leucaena leucocephala (Lmk) De Wit) in pregnant mice. J Indones Nat Ingredients 2006;6:33-5.

10. Hardani A. Mimosine Toxicity of Corcyra cephalonica Stainton Larvae (Pyralidae, Lepidoptera) (Thesis). Bogor: Bogor Pertanian University; 1984. p. 5.

11. Dita IA. Comparison of Mimosine Levels from the Seeds of (Leucaena leucocephala (Lam) de Wit) were Fermented using Aspergillus oryzae and Rhizopus oryzae (Thesis). Jakarta: Pharmacy Faculty of Pancasila University; 2014.

12. Prasetyo E. Glycemic Index Test and Analysis of Macro Nutrient Content from Soy Sauce Based (Leucaena leucocephala (Lam) de Wit) (Thesis). Jakarta: Faculty of Pharmacy Pancasia University; 2014. 